\title{
Klasifikasi Belimbing Menggunakan Nä̈ve Bayes Berdasarkan Fitur Warna RGB
}

\author{
Fuzy Yustika Manik ${ }^{1}$, Kana Saputra Saragih*2 \\ ${ }^{1}$ Manajemen Informatika, STMIK Kaputama, Binjai \\ ${ }^{2}$ Fakultas Ilmu Komputer, Universitas Pembangunan Panca Budi, Medan \\ e-mail: ${ }^{1}$ fuzy.yustika@gmail.com, $*^{2}$ kanasaputras@dosen.pancabudi.ac.id
}

\begin{abstract}
Abstrak
Permasalahan pasca panen pada buah belimbing yang diproduksi secara skala besar atau industri adalah penyortiran. Saat ini buah belimbing diklasifikasikan berdasarkan analisa warna kulit buah secara visual mata manusia. Metode ini tidak efektif dan efisien. Penelitian ini bertujuan untuk mengklasifikasikan buah belimbing berdasarkan tingkat kemanisan menggunakan teknik pemrosesan citra. Ekstraksi fitur yang digunakan adalah nilai Red, Green, dan Blue (RGB) untuk mendapatkan ciri pada citra warna. Kemudian hasil ekstraksi fitur tersebut digunakan untuk mengklasifikasikan buah belimbing dengan metode Nä̈ve Bayes. Data citra belimbing yang digunakan berjumlah 120 yang terdiri dari data latih berjumlah 90 dan data uji berjumlah 30. Hasil klasifikasi menunjukkan akurasi menggunakan ekstraksi ciri RGB sebesar $80 \%$. Penggunaan RGB sebagai ciri warna belum bisa digunakan sepenuhnya sebagai fitur dari citra buah belimbing.
\end{abstract}

Kata kunci-Belimbing, Ekstraksi Ciri, Klasifikasi, Naive Bayes, RGB

\begin{abstract}
Post harvest issues on star fruit produced on a large scale or industry is sorting. Currently, star fruits are classified by color analysis using human eye. This method is not effective and inefficient. This research aims to classify the starfruit sweetness level by using image processing techniques. Features extraction used is the value of Red, Green and Blue $(R G B)$ to obtain the characteristics of the color image. Then the feature extraction results are used to classify the star fruit with Nä̈ve Bayes method. The starfruit image data used are 120 images consisting of 90 training data and 30 testing data. The results showed the classification accuracy using RGB feature extraction is $80 \%$. The use of RGB as the color feature extraction can not be used entirely as a feature of the image extraction of star fruit.
\end{abstract}

Keywords - Starfruit, Feature Extraction, Classification, Naive Bayes, RGB

\section{PENDAHULUAN}

$\mathrm{P}$ ermasalahan produksi buah dalam skala besar adalah permasalahan pascapanen dalam hal penyortiran buah. Buah belimbing atau disebut juga starfruit digolongkan pada 3 kelas mutu buah belimbing yaitu kelas super, kelas A, dan kelas B. Salah satu cara pemilihan mutu buah adalah dengan memisahkan berdasarkan tingkat kemanisan. Selama ini buah diidentifikasi tingkat mutu rasa berdasarkan analisa warna kulit buah secara visual mata manusia yang memiliki keterbatasan. Proses identifikasi seperti ini memiliki beberapa kelemahan diantaranya yaitu membutuhkan tenaga lebih banyak untuk memilah, tingkat persepsi rasa buah yang berbeda, tingkat kekonsitenan manusia dalam hal menilai rasa buah 
tidak menjamin, karena manusia dapat mengalami kelelahan, sehingga dari fakta-fakta tersebut akan mempengaruhi waktu yang dibutuhkan dalam memilah dan mengidentifikasi tingkat kemanisan buah [1]. Untuk mengetahui tingkat kemanisan buah juga bisa dilakukan dengan melakukan pemeriksaan laboratorium kandungan Total Padat Terlarutnya (TPT). Akan tetapi analisis laboratorium ini akan menyebabkan buah yang diperiksa akan rusak. Oleh karena itu diperlukan teknik yang mampu memprediksi kemanisan buah belimbing tanpa merusaknya.

Beberapa penelitian tentang teknik pemrosesan citra telah banyak diterapkan untuk melakukan pemutuan terhadap buah. Salah satu penelitian tentang pemutuan buah belimbing manis menggunakan Probabilistic Neural Networks (PNN) menghasilkan akurasi sebesar $90.86 \%$ [2]. Sedangkan penelitian lain menggunakan Jaringan Syaraf Tiruan (JST) Multi-layer Perceptron untuk sistem sortasi buah belimbing menghasilkan akurasi sebesar 90,5\% [3]. Untuk penelitian menggunakan ekstraksi citra RGB dengan metode $k$-Nearest Neighbor (KNN) menghasilkan akurasi sebesar 83.33\% [4]. Penerapan metode Nä̈ve Bayes dan KNN sudah pernah dilakukan untuk mengklasifikasikan daun herbal. Hasilnya menunjukkan bahwa kinerja metode Nä̈ve Bayes Classifier lebih baik dibandingkan metode KNN dengan nilai akurasi Nä̈ve Bayes sebesar 75\%, sedangkan nilai akurasi KNN sebesar 70,83\% [5]. Metode Nä̈ve bayes juga digunakan untuk mengklasifikasikan tebu pada Dinas Kehutanan dan Perkebunan Pati. Hasil presentase kinerja metode Nä̈ve Bayes sebesar 73,3\% [6].

Buah belimbing merupakan salah satu jenis tanaman hortikultura yang memiliki nilai ekonomis tinggi. Hal tersebut disebabkan karena buah belimbing tidak hanya digunakan sebagai bahan pangan yang dikonsumsi dalam bentuk segar, namun juga beraneka ragam bentuk olahan sampai dengan bahan obat alami atau herbal [7].

Belimbing manis (Averrhoa carambola L) termasuk 1 dari 60 komoditas tanaman buahbuahan binaan Direktorat Jenderal Hortikultura Departemen Pertanian RI [7]. Dalam ilmu taksonomi, belimbing manis termasuk dalam divisi Spermatophyta, subdivisi Angiospermae, kelas Dicotyledonae, bangsa Geraniales, dan suku Oxalidaceae. Buah yang dikenal dengan nama starfruit dan terdapat di banyak daerah di Indonesia ini mempunyai khasiat sebagai obat batuk, dan obat tekanan darah tinggi [8]. Panjang buah berkisar dari 4 hingga $13 \mathrm{~cm}$ dengan warna hijau untuk buah muda dan kuning kehijauan untuk yang sudah tua.

Guna menjamin mutu dan meningkatkan daya saing produk, dilakukan penggolongan mutu terhadap belimbing manis. Sesuai dengan [8], dikenal 3 kelas mutu untuk belimbing manis, yakni: (1) kelas super, (2) kelas A, dan (3) kelas B. Hal ini penting agar produk belimbing yang dihasilkan dapat diterima konsumen sesuai segmennya. Oleh karena itu, salah satu penanganan pascapanen adalah melakukan sortasi buah sesuai mutu yang diinginkan.

Berdasarkan deskripsi diatas maka dilakukan penelitian untuk mengklasifikasikan mutu rasa buah belimbing secara tepat dengan bantuan komputer, yaitu menggunakan metode pengolahan citra digital dengan melakukan Pengenalan Total Padat Terlarut (TPT) buah belimbing berdasarkan nilai RGB dan klasifikasi menggunakan algoritma Nä̈ve Bayes. Proses pemisahan warna red $(\mathrm{R})$, green $(\mathrm{G})$, dan blue $(\mathrm{B})$, untuk mengetahui unsur warna yang lebih dominan untuk masing - masing kelas belimbing. Karena mutu buah belimbing yang terlihat dari total padat terlarut (TPT) dapat diketahui dari warna dominan pada buah belimbing tersebut.

\section{METODE PENELITIAN}

Metode penelitian yang dilakukan meliputi pengumpulan data citra belimbing, ekstraksi fitur RGB, pembagian data dengan $k$-fold cross validation, model klasifikasi dengan Naive Bayes, dan evaluasi model dengan melihat hasil klasifikasi menggunakan confusion matrix. Tahapan penelitian dapat dilihat pada Gambar 1.

IJCCS Vol. 11, No. 1, January 2017 : $99-108$ 


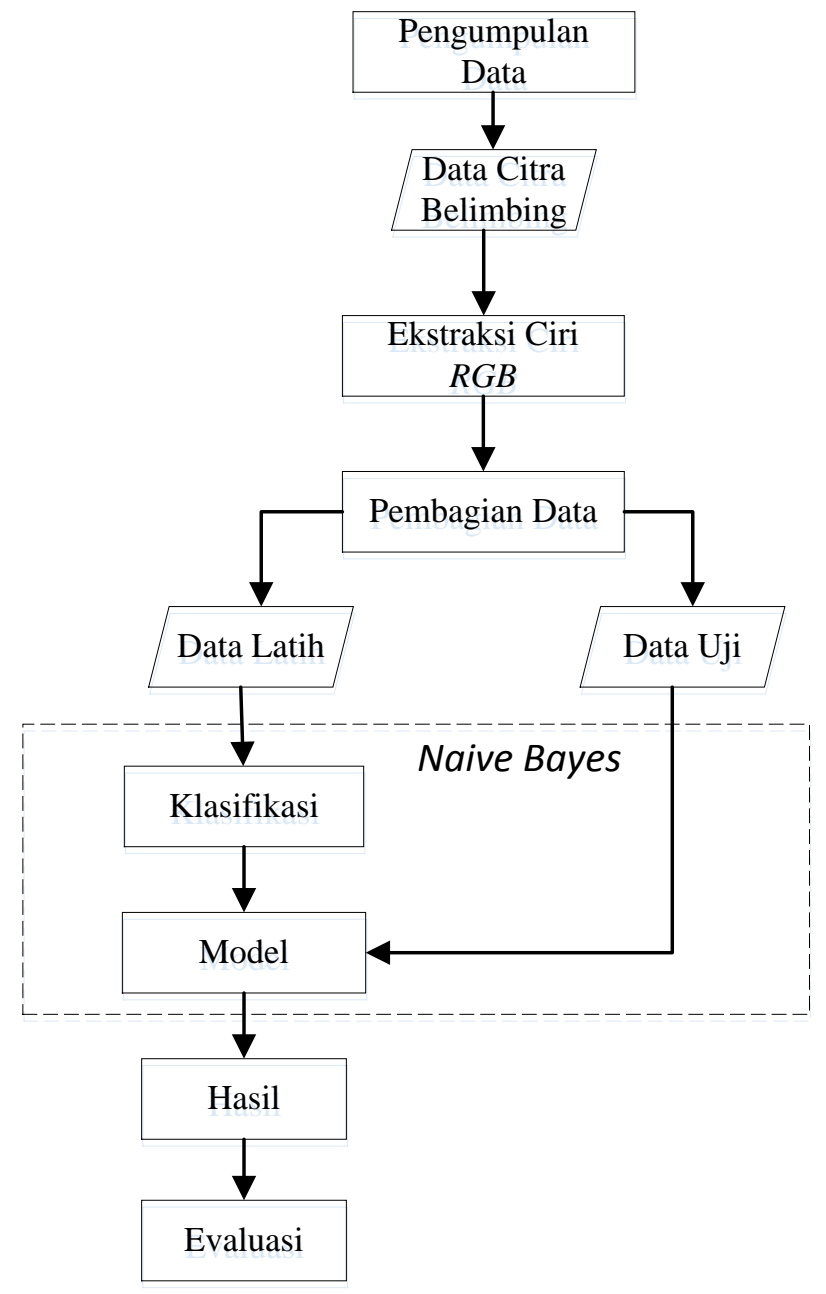

Gambar 1 Tahapan Penelitian

\subsection{Pengumpulan Data}

Data yang digunakan adalah citra belimbing yang terdiri dari belimbing asam untuk kelas B, belimbing sedang untuk kelas A, dan belimbing manis untuk kelas super. Jumlah citra belimbing yang diperoleh berjumlah 120 citra belimbing. Belimbing merupakan salah satu tanaman buah eksotis yang cukup banyak digemari berbagai lapisan masyarakat. Manfaat utama tanaman ini adalah sebagai penghasil buah segar, bahan buah olahan, dan juga obat tadisional. Menurut sejarah, tanaman belimbing berasal dari kawasan Malaysia, kemudian menyebar luas ke berbagai negara yang beriklim tropis lainnya di dunia, termasuk Indonesia. Pada umumnya belimbing ditanam dalam bentuk kultur pekarangan, sebagai usaha sambilan atau tanaman peneduh di halaman-halaman rumah.

Belimbing dibedakan atas dua macam, yaitu belimbing manis (Averrhoa carambola L.) dan belimbing wuluh (Averhoa belimbi L.). Belimbing wuluh sering digunakan untuk bumbu masakan, terutama untuk memberi rasa asam pada masakan. Dalam sistematika tumbuhan, belimbing manis diklasifikasikan sebagai berikut:

$\begin{array}{ll}\text { Kingdom } & : \text { Plantae } \\ \text { Divisi } & \text { : Spermatopyta } \\ \text { Sub divisi } & : \text { Angiospermae } \\ \text { Kelas } & \text { : Dicotyledone }\end{array}$




$\begin{array}{ll}\text { Ordo } & : \text { Oxalidales } \\ \text { Famili } & \text { : Oxalidaceae } \\ \text { Genus } & : \text { Avverrhoa } \\ \text { Species } & : \text { Averrhoa carambola L. }\end{array}$

Belimbing manis memiliki banyak kandungan gizi yang terkandung di dalamnya. Belimbing manis mengandung protein, lemak, kalsium, fosfor, besi, vitamin B, vitamin C, vitamin A kalium dan serat. Kandungan kalorinya rendah sehingga baik untuk diet [8].

\section{2 Ekstraksi Ciri}

Untuk mengetahui suatu citra, diperlukan adanya ekstraksi ciri. Ekstraksi ciri dapat diteliti dengan mengambil beberapa bagian citra yang bisa menunjukan ciri khas dari citra tersebut, misalkan warna, pola citra, diameter, bentuk dan masih banyak lagi. Citra warna merupakan citra digital yang memiliki kombinasi warna Red, Green dan Blue ditunjukkan pada Gambar 2.

Teknik yang digunakan adalah dengan mengekstrak citra RGB (Red-Green-Blue) buah belimbing menjadi beberapa nilai ciri, seperti jumlah $\mathrm{R}$, jumlah $\mathrm{G}$, jumlah $\mathrm{B}$, mean dan standar deviasi dari citra buah belimbing. Untuk satu buah, nilai ciri tersebut diperoleh dengan merataratakan atau menjumlahkan semua piksel yang ada, dan berdasar nilai inilah dilakukan pengenalan. Jadi dari teknik yang ada, proses pengenalan tidak berdasarkan semua piksel tetapi berdasarkan besaran yang merupakan rata-rata atau jumlah dari semua piksel [4].
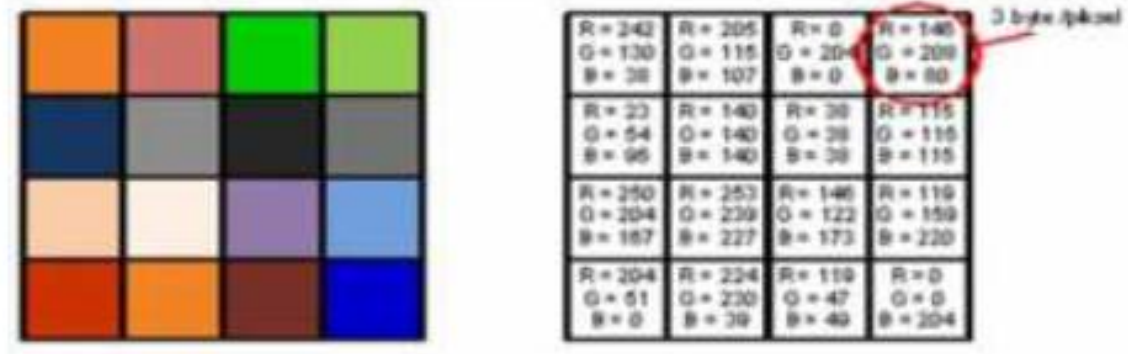

Gambar 2 Representasi Citra Warna RGB

\section{3 Pembagian Data}

Seluruh data hasil ekstraksi masing-masing ciri dibagi menjadi data latih dan data uji. Persentase data latih yang dicobakan pada penelitian ini ditentukan dengan menggunakan $k$-fold cross validation.

$k$-fold cross validation adalah metode yang digunakan untuk membagi dataset menjadi sejumlah $k$ buah partisi secara acak. Data awal dibagi menjadi $k$ subset secara acak yaitu $D_{1}, D_{2}, D_{3}, \ldots, D_{k}$, dengan ukuran subset yang hampir sama dengan mempertahankan perbandingan antar kelas. Langkahnya adalah dengan melakukan iterasi sejumlah $k$ kali iterasi untuk data latih dan data uji, dimana masing-masing iterasi menggunakan partisi ke $k$ sebagai data latih dan sisa partisi lainnya sebagai data uji. Keuntungan $k$-fold cross validation adalah semua data digunakan baik untuk data uji maupun data latih. Hal ini dilakukan untuk mendapatkan nilai akurasi ataupun ukuran penilaian lainnya dari hasil eksperimen yang dilakukan [9].

Jumlah $\mathrm{k}$ yang digunakan adalah 3. Mengingat data yang digunakan untuk pelatihan sedikit, pemilihan 3-fold cross validation cukup mampu untuk membuat variasi data, sehingga semua data digunakan, baik untuk data uji maupun data latih. Seluruh data hasil ekstraksi ciri 
dibagi menjadi 3 subset, yaitu D1, D2, D3. Masing-masing subset memiliki ukuran yang sama. Pada proses pertama D2, D3 menjadi data pelatihan dan D1 menjadi data pengujian, pada proses kedua D1, D3, menjadi data pelatihan dan D2 menjadi data pengujian, dan seterusnya.

\section{4 Implementasi Metode Naive Bayes}

Nä̈ve Bayes merupakan salah satu metode machine learning yang menggunakan perhitungan probabilitas. Algoritma ini memanfaatkan metode probabilitas dan statistic sederhana dengan asumsi bahwa antar satu kelas dengan kelas yang lain tidak saling tergantung (independen) [10]. Dasar dari Naïve Bayes yang dipakai dalam pemrograman adalah persamaan (1) Bayes [11] :

$P(Y \mid X)=\frac{P(Y) \prod_{i=1}^{q} P\left(X_{i} \mid Y\right)}{P(X)}$

Keterangan:

$P(Y \mid X) \quad$ : probabilitas data dengan vektor X pada kelas $\mathrm{Y}$

$P(Y) \quad$ : probabilitas awal kelas $\mathrm{Y}$ (prior probability)

$\prod_{i=1}^{q} P\left(X_{i} \mid Y\right) \quad:$ probabilitas independen kelas $\mathrm{Y}$ dari semua fitur dalam vektor $\mathrm{X}$

$P(X) \quad$ : probabilitas dari $\mathrm{X}$

Data yang digunakan dapat bersifat kategorial maupun kontinyu. Untuk data kontinyu dapat diselesaikan dengan menggunakan langkah-langkah berikut.

1. Hitung probabilitas (Prior) tiap kelas yang ada.

2. Lalu hitung rata-rata (mean) tiap fitur dengan persamaan (2).

$\mu=\frac{\sum n}{k}$

Keterangan :

$\mathrm{k}=$ banyaknya data

$\mathrm{n}=$ nilai data

3. Kemudian hitung nilai standar deviasi dari fitur tersebut seperti pada persamaan (3) .

$s d=\sqrt{\frac{n \sum_{i=1}^{n}\left(x_{i}-\bar{x}\right)^{2}}{(n-1)}}$

Selanjutnya menghitung densitas probabilitasnya menggunakan persamaan (4).

$\varphi_{\mu, \sigma}(x)=\frac{1}{\sqrt{2 \pi \sigma^{2}}} e^{-\frac{(x-\mu)^{2}}{2 \sigma^{2}}}$

Setelah didapatkan nilai densitas probabilitas dan prior, hitung probabilitas masing-masing kelas dengan menggunakan persamaan (5).

$P=P(X \mid C i) x P(C i)$ 
Nilai probabilitas terbesar adalah kelas yang sesuai. Sedangkan untuk data kategorial, hanya memerlukan semua kemungkinan yang terjadi.

Naïve Bayes adalah algoritma yang termasuk ke dalam supervised learning, maka akan dibutuhkan pengetahuan awal untuk dapat mengambil keputusan. Proses klasifikasi dengan Naïve Bayes dilakukan menggunakan data latih yang sebelumnya sudah dibagi menggunakan $k$ fold cross validation. Dalam melakukan pelatihan dan pengujian data, karakter akan diambil satu per satu dari fitur yang ada. Klasifikasi yang akan dilakukan adalah didasarkan ciri-ciri warna buah belimbing yang menunjukkan buah belimbing tersebut manis, sedang atau asam. Terdapat 2 proses dalam klasifikasi ini yaitu: tahap training dengan memakai data yang ada, membangun metode untuk mengestimasi parameter dari distribusi peluangnya dengan asumsi bahwa adanya independensi dari masing-masing kelas (data dengan karakteristik yang sama). Dalam tahapan ini dilakukan estimasi pada parameter $\boldsymbol{\theta}$ dengan Maximum Likelihood (ML), dan tahap prediksi yaitu proses menggunakan model yang sudah dibangun tersebut untuk melakukan tes data untuk memperkirakan/mengukur akurasi dari aturan yang dibentuk dalam model dengan menghitung peluang posterior kemudian mengklasifikasi kedalam peluang posterior terbesar MAPH (Maximum A Posteriori Hypothesis).

\section{5 Evaluasi}

Tahapan ini merupakan tahapan untuk menganalisis dan mengevaluasi model yang diperoleh dari masing model yang digunakan. Proses perhitungan akurasi hasil klasifikasi menggunakan rumus Confusion matrix. Confusion matrix merupakan sebuah tabel yang terdiri atas banyaknya baris data uji yang diprediksi benar dan tidak benar oleh model klasifikasi. Tabel confusion matrix diperlukan untuk menentukan kinerja suatu model klasifikasi [12]. Ada empat istilah yang digunakan dalam confusion matrix yaitu:

1. True positive (TP): jumlah data positif yang benar diklasifikasi oleh classifier.

2. True negative (TN): jumlah data negatif yang benar diklasifikasi oleh classifier.

3. False positive (FP): jumlah data negatif yang salah diklasifikasi sebagai data positif.

4. False negative (FN): jumlah data positif yang salah diklasifikasi sebagai data negatif.

Contoh tabel confusion matrix prediksi kelas dapat dilihat pada Tabel 1.

Tabel 1 Confusion matrix Prediksi Kelas

\begin{tabular}{|l|l|l|}
\hline Kelas Sebenarnya & Positive & Negative \\
\hline Positive & A: True Positive & B: False negative \\
\hline Negative & C: False positive & D: True negative \\
\hline
\end{tabular}

Berdasarkan tabel confusion matrik di atas akurasi dapat dihitung dengan persamaan (6) seperti berikut:

Akurasi $=\frac{\sum A+\sum D}{\sum A+\sum B+\sum C+\sum D} \times 100 \%$

\section{HASIL DAN PEMBAHASAN}

Pengujian dilakukan dengan tujuan untuk mengetahui keberhasilan sistem dalam mengklasifikasi rasa dari buah belimbing, apakah manis, sedang dan asam. Skenario uji coba 
yang dilakukan dengan jumlah data gambar dari buah belimbing, yaitu sebanyak 120 gambar. Masing-masing jumlah gambar dari tingkat kemanisan buah belimbing seperti terlihat pada Tabel 2.

Tabel 2 Jumlah Data yang Digunakan

\begin{tabular}{|c|l|c|}
\hline No & Tingkat Kemanisan Buah Belimbing & Jumlah \\
\hline 1 & Asam & 40 \\
\hline 2 & Sedang & 40 \\
\hline 3 & Manis Jumlah Citra & 40 \\
\hline \multicolumn{2}{|c|}{} & 120 \\
\hline
\end{tabular}

Pengujian dilakukan dengan cara memisahkan data menjadi dua bagian yaitu $80 \%$ digunakan sebagai data latih dan $20 \%$ digunakan sebagai data uji. Beberapa sampel citra yang telah terkumpul seperti yang ditunjukkan pada Gambar 3 .

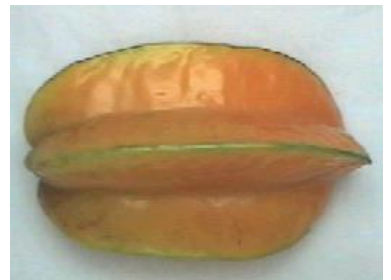

(a)

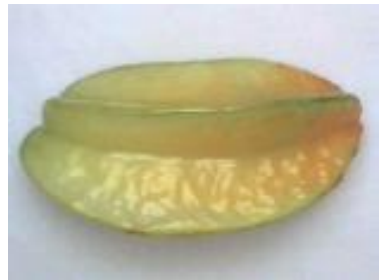

(b)

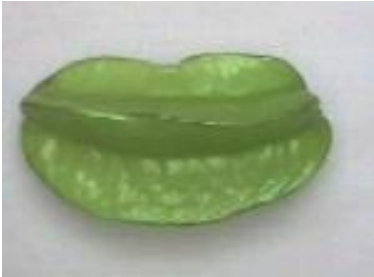

(c)

Gambar 3 Citra Sampel Belimbing (a) Manis (b) Sedang (c) Asam

\subsection{Hasil Ektraksi Fitur}

Praproses dilakukan dengan terlebih dahulu melakukan segmentasi. Proses ini diperlukan untuk memisahkan objek citra belimbing dengan latar belakangnya. Segmentasi sangat diperlukan untuk menentukan piksel yang akan dianalisis. Pada tahap ektraksi fitur dilakukan ektraksi fitur yang berisi 5 nilai yaitu dari fitur warna $R, G, B$, ean dan fitur standar deviasi dari citra belimbing seperti pada Gambar 4. Untuk satu buah belimbing, nilai ciri tersebut diperoleh dengan merata-ratakan atau menjumlahkan semua piksel yang ada, dan berdasar nilai inilah dilakukan pengenalan.

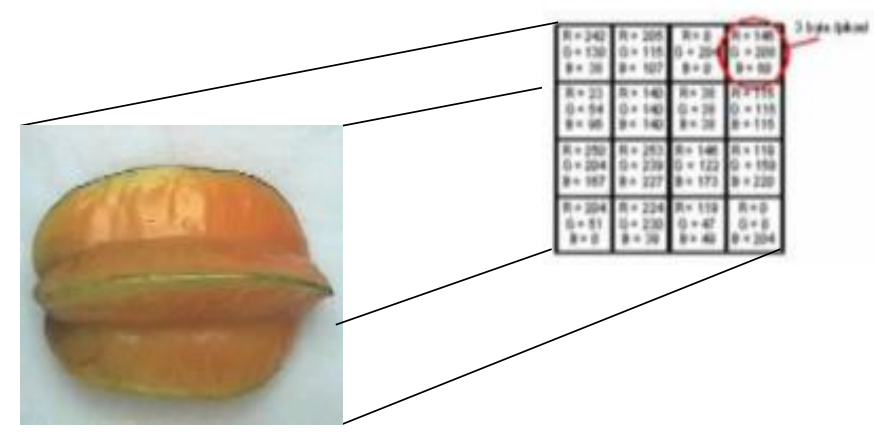

Gambar 4 Ekstraksi Fitur Warna RGB 
Berikut contoh nilai hasil ektraksi fitur dapat dilihat pada Tabel 3.

Tabel 3 Contoh Hasil Ekstraksi Fitur Citra Buah Belimbing

\begin{tabular}{|c|c|c|c|c|c|c|}
\hline Citra & $\mathrm{R}$ & $\mathrm{G}$ & $\mathrm{B}$ & Mean & Std & Jenis \\
\hline as1 & 169.67 & 186.40 & 142.46 & 166.18 & 22.17 & Asam \\
\hline as2 & 167.92 & 180.78 & 144.57 & 164.42 & 18.36 & Asam \\
\hline as3 & 169.01 & 180.37 & 144.23 & 164.54 & 18.48 & Asam \\
\hline sed1 & 181.39 & 181.26 & 144.27 & 168.97 & 21.39 & Sedang \\
\hline sed2 & 195.34 & 188.01 & 158.53 & 180.63 & 19.48 & Sedang \\
\hline sed3 & 196.92 & 194.25 & 159.50 & 183.56 & 20.88 & Sedang \\
\hline man1 & 204.23 & 187.67 & 154.23 & 182.04 & 25.47 & Manis \\
\hline man2 & 186.94 & 160.68 & 124.49 & 157.37 & 31.36 & Manis \\
\hline man3 & 190.57 & 181.18 & 159.28 & 177.01 & 16.06 & Manis \\
\hline
\end{tabular}

\subsection{Hasil Klasifikasi}

Proses training bertujuan untuk membangun model klasifikasi. Berdasarkan Tabel 4 diketahui bahwa akurasi terbesar yang diperoleh dari tiga kali percobaan terdapat pada fold 2 sebesar $83.33 \%$, akan tetapi untuk menghindari terjadinya overfitting, maka dihitung rata-rata dari model 3-fold cross validation. Kemudian hasil rata-rata dibandingkan dengan ketiga model tersebut. Fold 3 dipilih sebagai model Naive Bayes karena nilai fold 3 mendekati nilai rata-rata yang diperoleh.

Tabel 4 Akurasi Klasifikasi Tingkat Kemanisan Buah Belimbing

\begin{tabular}{|c|c|}
\hline Fold & Akurasi \\
\hline 1 & $60 \%$ \\
\hline 2 & $83.33 \%$ \\
\hline 3 & $70 \%$ \\
\hline Rata-rata & $71.11 \%$ \\
\hline
\end{tabular}

Pengujian hasil klasifikasi dilakukan terhadap 30 citra buah belimbing yang diperoleh dari perbandingan data latih dan data uji sebesar $80 \%$ dan 20\%. Data uji akan diklasifikasikan terhadap data training.

Tabel 5 Confusion Matrix Klasifikasi Buah Belimbing

\begin{tabular}{|c|c|c|c|c|c|}
\hline & \multicolumn{3}{|c|}{ Kelas Prediksi } & \multirow{2}{*}{ Total } \\
\hline & & Asam & Sedang & Manis & \\
\hline \multirow{3}{*}{$\begin{array}{c}\text { Kelas } \\
\text { Sebenarnya }\end{array}$} & Asam & 10 & 0 & 0 & 10 \\
\hline & Sedang & 0 & 7 & 3 & 10 \\
\hline & Manis & 0 & 3 & 7 & 10 \\
\hline
\end{tabular}

Berdasarkan Tabel 5 diketahui metode Nä̈ve Bayes untuk tingkat kemanisan sedang dan manis masih terjadi kesalahan klasifikasi. Hal ini terjadi karena fitur warna buah belimbing yang asam sangat berbeda dengan fitur warna buah belimbing yang memiliki tingkat kemanisan sedang dan manis. Penggunaan warna RGB sebagai ekstraksi ciri warna belum bisa digunakan sepenuhnya sebagai ektraksi fitur dari citra buah belimbing. 


\subsection{Evaluasi}

Hasil klasifikasi dari tingkat kemanisan buah belimbing tersebut kemudian dihitung nilai akurasinya, dengan cara membagi jumlah dari data uji setiap kelas yang diklasifikasikan secara benar dengan total dari data uji. Berdasarkan hasil klasifikasi yang terlihat pada Tabel 5 diperoleh nilai akurasi untuk tiap tingkat kemanisan buah belimbing seperti pada Tabel 6 .

Tabel 6 Akurasi Hasil Klasifikasi Buah Belimbing

\begin{tabular}{|c|c|}
\hline Kelas & Akurasi \\
\hline Asam & $100 \%$ \\
\hline Sedang & $70 \%$ \\
\hline Manis & $70 \%$ \\
\hline Rata-rata & $80 \%$ \\
\hline
\end{tabular}

Berdasarkan Tabel 6 diketahui bahwa rata-rata akurasi metode Naïve Bayes sebesar $80 \%$. Hasil klasifikasi menggunakan algoritma Nä̈ve Bayes masih terlalu rendah dibandingkan algoritma lain. Oleh karena itu, dibutuhkan ekstrasi ciri tambahan untuk mendukung model klasifikasi yang akan dibentuk.. Masih perlu ditambahkan ektraksi fitur lainnya seperti tektur, morfologi ataupun geometri.

\section{KESIMPULAN}

Ekstraksi fitur warna RGB dapat digunakan untuk ekstraksi ciri pada citra. Hasil ekstraksi ciri digunakan sebagai input bagi Nä̈ve Bayes untuk mengenal pola citra dan mengklasifikasikan tingkat kemanisan buah belimbing. Hasil klasifikasi menunjukkan tingkat akurasi menggunakan ekstraksi ciri warna RGB sebesar 80\%. Keberhasilan mengidentifikasikan juga dipengaruhi oleh fitur-fitur yang digunakan sebagai penciri pada metode klasifikasi tersebut. Rendahnya hasil akurasi menyebabkan perlu adanya penambahan fitur lain seperti tektur, morfologi ataupun geometri.

\section{SARAN}

Hasil klasifikasi menggunakan algoritma Nä̈ve Bayes masih terlalu rendah dibandingkan algoritma lain. Oleh karena itu, dibutuhkan ekstrasi ciri tambahan untuk mendukung model klasifikasi yang akan dibentuk. Penambahan ektraksi ciri dapat berupa ciri morfologi atau geometri dari data citra yang diperoleh.

\section{DAFTAR PUSTAKA}

[1] Sugianto S dan Wibowo F, 2015, Klasifikasi Tingkat Kematangan Buah Pepaya (Carica Papaya L) California (Callina-Ipb 9) Dalam Ruang Warna HSV dan Algoritma K-Nearest Neighbor, Prosiding Senatek, Purwokerto, 28 November

[2] Zaki F, 2009, Pengembangan Probabilistic Neural Networks Untik Penentuan Kematangan Belimbing Manis, Skripsi, Jurusan Ilmu Komputer, Institut Pertanian Bogor, Bogor.

[3] Abdullah M.Z, M Saleh J, Syahir F.A.S, dan M Azemi B.M.N, 2006, Discrimination and Classification of Fresh-cut Starfruits (Averrhoa Carambola L) using Automated Machine Vision System, Jurnal of Food Engeneering 
[4] Saputra K dan Manik F.Y,2016, Klasifikasi Belimbing Menggunakan K-Nearest Neighbors (KNN) Berdasarkan Citra Red-Green-Blue (RGB), Prosiding SEMMAU 2016, Kupang, 17 September

[5] Liontoni F dan Nugroho H. 2015. Klasifikasi Klasifikasi Daun Herbal Menggunakan Metode Naïve Bayes Classifier Dan Knearest Neighbor. Jurnal Simantec

[6] Anandita E.R, 2014, Klasifikasi Tebu Dengan Menggunakan Algoritma Naïve Bayes Classification Pada Dinas Kehutanan dan Perkebunan Pati, Skripsi, Jurusan Sistem Informasi, Universitas Dian Nuswantoro, Semarang.

[7] Balai Pengkajian Teknologi Pertanian, 2008, Pupuk \& Pemupukan Tanaman Belimbing, Jakarta.

[8] Yulandari S, 2013, Hubungan Tingkat Pengetahuan Dengan Tingkat Konsumsi Buah dan Sayur Pada Anak Kelas IV-V SD Pertiwi, Skripsi, Fakultas Keperawatan, Universitas Andalas,Padang.

[9] Han J, Kamber M, Pei J, 2012, Data Mining: Concepts and Techniques. 3th ed, New York (US): Morgan Kaufman Elsevier Academic Pr.

[10] Nugroho A dan Subahar, 2013, Klasifikasi Naïve Bayes Untuk Prediksi Kelahiran Pada Data Ibu Hamil. Berkala Mipa, Vol 23, Ed 3.

[11] Prasetyo E, 2012, Data Mining : Konsep dan Aplikasi Menggunakan Matlab, Penerbit Andi, Yogyakarta

[12] Tan PN, Steinbach M, Kumar V, 2005, Introduction to data mining, New York (US): Addison Wesley 